\title{
Island climate change adaptation and global public goods within the Belt and Road Initiative
}

\author{
Chunlin Li \\ Law School, Fuzhou University, China \\ chunlinli@fzu.edu.cn \\ Jianqing Chen \\ Law School, Fuzhou University, China \\ aaronpower@foxmail.com (corresponding author)
}

\author{
Adam Grydehøj \\ Island and Coastal Zone Institute, Urban and Rural Innovation Design Research Center, \\ Zhejiang University, China \\ agrydehoj@islanddynamics.org
}

\begin{abstract}
The Belt and Road Initiative (BRI), a project conceptualized and developed by the Chinese state, aims to enhance international cooperation, address issues of shared regional and global concern, and create opportunities for foreign direct investment in struggling economies. The BRI can be seen as a system for supplying global public goods, including sustainable development within which issues related to climate change sit. A great many small island states and territories are participating in the BRI, particularly in its constituent 21stCentury Maritime Silk Road. However, the BRI has not yet placed sufficient focus on climate change adaptation or issues specific to small islands. Furthermore, the BRI's conceptual basis in rhetoric of mutual dependence and a community of common destiny have not always been evident in the individual activities that have been carried out within the BRI. If the BRI's goals are to be taken seriously, it must do more to focus on the needs and perspectives of island communities, particularly with regard to climate change adaptation. This paper presents a framework for action to strengthen the BRI's approach to islands and climate change adaptation in terms of information sharing, scientific and technological cooperation, financial support, and capacity building within a global governance framework.
\end{abstract}

Keywords: Belt and Road Initiative, China, climate change adaptation, cooperation, islands, global governance

https://doi.org/10.24043/isj.134 • Received September 2019, accepted October 2020

(C) 2020-Institute of Island Studies, University of Prince Edward Island, Canada. 


\section{Introduction}

In 2013, China's central government introduced an initiative to jointly build a Silk Road Economic Belt and a 21st-Century Maritime Silk Road. This project has come to be collectively referred to as the Belt and Road Initiative (hereafter, BRI). The BRI's mechanisms and motivations are complex: it is undeniably interested in boosting the Chinese economy, opening up new markets for Chinese products, and securing the resources necessary for future Chinese growth. At the same time, however, the Chinese government has conceptualized the BRI as a means of enhancing international cooperation, addressing issues of shared regional and global concern, and creating opportunities for foreign direct investment in struggling economies (Mitrovic, 2018).

Such motivations are not necessarily mutually exclusive; it is entirely possible for other countries to benefit from strengthened economic links with China. Yet neither should these motivations be assumed to be automatically compatible; some activities and practices undertaken by Chinese businesses operating overseas may be harmful to host countries. Such disconnects are made more likely by the fact that, whereas the BRI has been conceptualized by China's central government, many of the individual projects that are carried out under its umbrella are led by corporate actors that may not prioritize grand visions of "win-win cooperation" and "inclusive and sustainable" development (Xi, 2015). As Winter (2018, p. 10) notes, whatever else it may be, the BRI is a project that "places China at the political, economic, and cultural center of a vast geography of overland and maritime connectivity." For better or for worse, China is of increasing importance to a wide range of countries.

Perhaps emblematic of these tensions are issues related to climate change as part of sustainability. Many countries seek to use the BRI as leverage for obtaining Chinese support in the form of information sharing, scientific and technological cooperation, financial support, and capacity building, yet targeted climate change adaptation and other sustainability projects have thus far been quite far down the agenda when it has come to putting the BRI into practice (Chen et al, 2020).

The BRI has grown over the years to include countries around the world: 65 countries (including regions) as of July 2020. Among these are a great many of the world's small island states and large islands and archipelagos, including: Antigua and Barbuda, Bahrain, Cook Islands, Cuba, Dominica, Fiji, Grenada, Indonesia, Jamaica, Kiribati, Madagascar, Maldives, Malta, Mauritius, New Zealand, Niue, Papua New Guinea, Philippines, Samoa, Seychelles, Singapore, Sri Lanka Tonga, Trinidad and Tobago, and Vanuatu. Numerous states that combine both island and mainland territories have also signed up to elements of the BRI project.

We believe that the BRI currently devotes insufficient attention to the needs of island communities in particular. The present paper asks how China might refocus its streams of investment and modes of engagement within the BRI-conceptualized as a framework for global governance with the potential to provide global public goods - to better meet the needs of island states and territories that face challenges related to sustainable development, including climate change adaptation. Such questioning is vital not because the BRI is necessarily the only or even the best potential route to climate change adaptation for small island communities. It is vital simply because China, through the BRI process, is already having a major impact on island communities around the world. It may thus be beneficial to consider how Chinese activities can better address the reality of their own role in a changing global climate. 


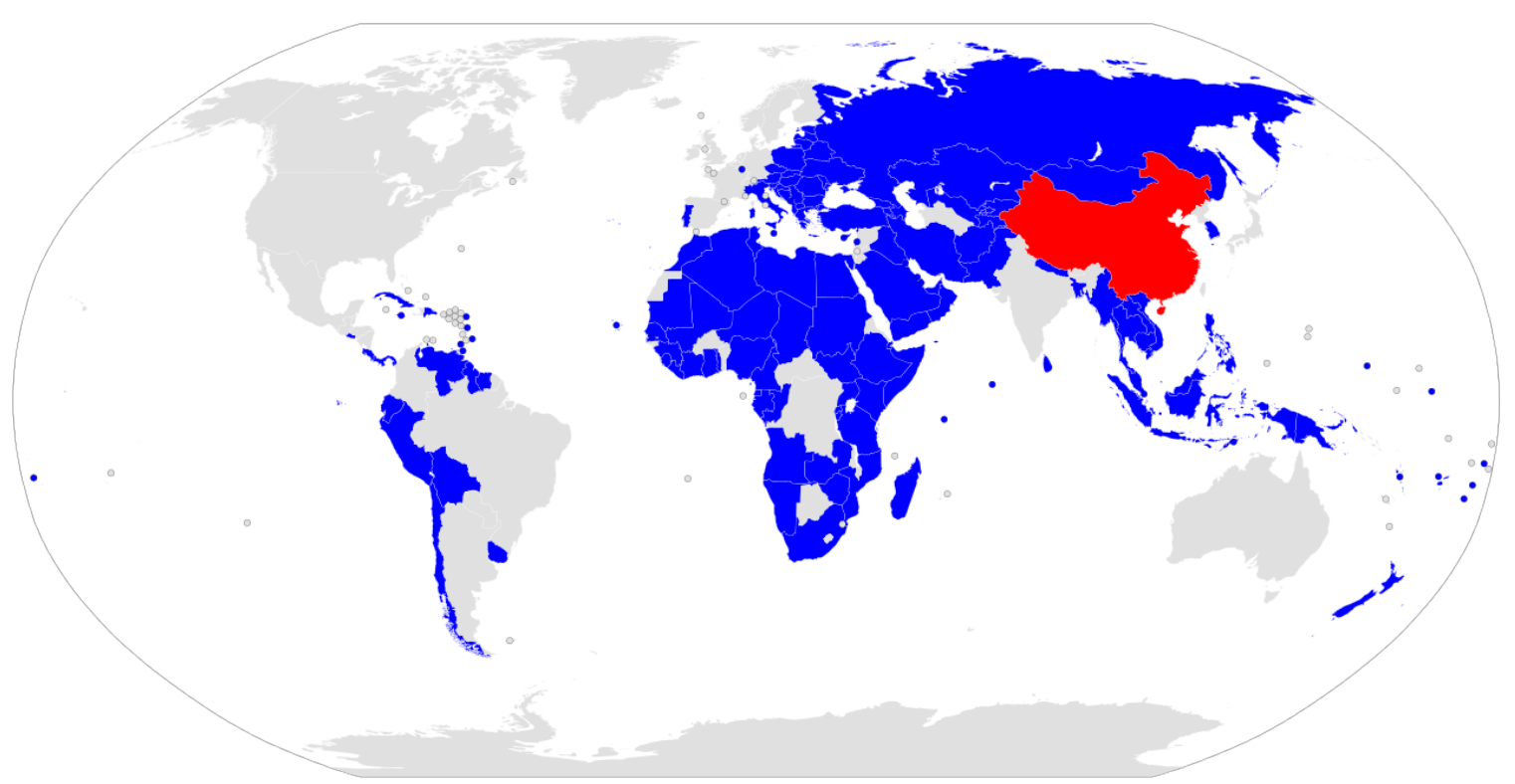

Figure 1. Countries that have engaged in the Belt and Road Initiative. Source: Owennson, 26 January 2020 , https://en.wikipedia.org/wiki/File:Belt and Road Initiative participant map.svg

Although the Chinese government envisions the BRI as a set of multilateral and bilateral relationships of equality, China is at present the driving force behind and major funder of the BRI project. As such, no study that considers the challenges and opportunities of the BRI can truly be said to present an 'island perspective'. We are not researching "islands on their own terms" (McCall, 1994). We do, however, seek to counter the "peripheralisation of archipelagic cultures" (Gómez-Barris \& Joseph, 2019, p. 3) by arguing that, if the BRI's stated aims are to be taken seriously, then the fate of islands and archipelagoes must be regarded as central to them, and island interests must not be neglected in the BRI's development.

\section{Global public goods}

As interrelations between people and places around the world increase, so too does the need to think globally when it comes to considering national or local interests. Recognition of interdependency in our globalized world makes it necessary to conceive of shared public goods. If needs and interests are shared, then those goods that meet these needs and interests must be shared as well.

For Speth (1999, p. xii), "in many areas of public policy, what were once considered to be purely national issues now spill across borders [...] A globalizing world requires a theory of global public goods to achieve crucial goals such as financial stability, human security or the reduction of environmental pollution." Kaul, Grunberg, and Stern (1999, pp. 2-3) identify two criteria for 'global public goods':

The first is that their benefits have strong qualities of publicness - that is, they are marked by nonrivalry in consumption and nonexcludability. These features place them in the general category of public goods. The second criterion is that their benefits are quasi universal in terms of countries (covering more than one group of countries), 
people (accruing to several, preferably all, population groups), and generations (extending to both current and future generations, or at least meeting the needs of current generations without foreclosing development options for future generations).

The existing system of international cooperation and global governance has struggled to produce, supply, and distribute such public goods on a global basis in part because, even as globalization has altered traditional hierarchies of power (Fidler, 2003), this system takes the nation-state as standard and assumes the dominance of major powers. With its starting point of rational pursuit of self-interest by the state (Qin, 2018), mainstream international systems can only with difficulty be adapted to today's shared needs and realities.

Alternative systems of addressing global needs are called for. The BRI is not the only potential system, but as we shall see, it is at present unusual in being a large, well-supported system (albeit funded and promoted largely by a single country) that is explicitly conceptualized as a framework for collective decisionmaking and pursuit of shared interest in a world characterized by interdependency.

\section{The Belt and Road Initiative}

\section{Intellectual origins of the Belt and Road Initiative}

The BRI emerged out of China's late- $20^{\text {th }}$ and early-2 $1^{\text {st }}$-Century reform and opening-up policy. It represents an attempt by an increasingly confident Chinese state-which had never been particularly well-served by the existing international system (Qin, 2003) — to adapt to the changing global reality, a reality that includes China's rise as an influential international actor.

China's National Development and Reform Commission, Ministry of Foreign Affairs, and Ministry of Commerce (2015) assert that the joint construction of the BRI is in the interests of the world community and that the BRI should serve as a pathway toward new models of international cooperation and global governance, reflecting shared ideals and values. The BRI has, of course, been designed by China, and it is intended to promote economic and social development within China. It is, however, grounded in a political philosophy that sees a state's development as dependent upon the simultaneous development of partner countries or, more radically, sees all countries as mutually dependent upon one another (Ren, 2020; Qin, 2018; Zhao, 2009). In either case, this leads the Chinese state to pursue "the moral high ground" and emphasize the importance of international cooperation to advance shared interests and achieve world peace (Zhang, 2013). Such a strategy is fundamentally aimed at complementing, replacing, or repurposing existing regional or global mechanisms for promoting economic development, public health, environmental protection, and so on, which are seen as hampered by their being structured around systems of interstate competition: part of the reason why such mechanisms fail to provide effective global governance is that they were designed to maintain stability among a set of distinct state powers. It is thus that the BRI has been explicitly conceptualized as pursuing shared interests and providing global public goods (He, 2018).

Such ideals are not always achieved in practice, and other theories of international relations are also discussed in China (e.g. Yan, 2019), but it is this cluster of cooperationoriented theories that has acquired rhetorical prominence in both the policy documents undergirding the BRI and Chinese government statements regarding its international 
priorities more generally. It is thus that the Chinese state is increasingly intent not just on engaging internationally but on actively encouraging multilateralism (Lanteigne, 2018).

\section{Framework for the Belt and Road Initiative}

The BRI may be regarded as an initiative, project, plan, program, process, strategy, or vision (Puig, 2020). It is in any case designed as a new global development cooperation system for addressing the shortcomings of the existing international model of production, supply, and distribution of global public goods and of managing global problems. Although the BRI is represented as reviving the spirit of inter-regional cooperation and development that characterized the ancient Silk Road, it is a fundamentally modern construction (Xie, Zhu, \& Grydehøj, 2020; Winter, 2018). The rhetoric of ancient historical connections and transnational cultural heritage is politically interesting and may strengthen the BRI project, but it is not of critical importance to the mass of more-or-less mundane activities that occur beneath the BRI umbrella.

Unlike the mainstream international cooperation model (with its point of departure in the competing interests of independent, bounded state entities), the BRI's vision of international cooperation focuses on shared needs and joint responsibilities (Dunford \& Liu, 2019). This distinction may be somewhat philosophical, and it may not always be evident in all activities attributed to the BRI, but it remains important to consider that the BRI has been expressly conceptualized as mitigating against the 'free-rider problem' and as optimizing the pursuit of global public goods (Chun, 2017).

As a new model of international development, the BRI's basic framework has been described as a three-part structure consisting of 1) areas of cooperation, 2) principles of cooperation, and 3) objectives of cooperation (National Development and Reform Commission, 2015).

There are five key areas in the BRI (National Development and Reform Commission, Ministry of Foreign Affairs, \& Ministry of Commerce, 2015). 1) Policy coordination: Governments within the BRI should strengthen dialogue regarding macroeconomic policies, fully communicate economic development strategies, and jointly formulate initiatives to promote regional cooperation. 2) Facilities connectivity: Countries within the BRI should create shared infrastructure planning and technical standards systems, jointly promote the construction of key international channels, and form an infrastructure network connecting the various regions of Asia, Europe, Africa, and the Pacific. 3) Barrier-free trade: Countries within the BRI should eliminate investment barriers and trade barriers as well as jointly negotiate the establishment of free trade zones to promote integrated development. 4) Financial integration: Countries within the BRI should strengthen bilateral and multilateral financial cooperation through the establishment of financial institutions for regional development and other channels to provide financial support for economic and trade cooperation. 5) Intercommunity bonding: Countries within the BRI should deepen friendship among their peoples, enhance mutual understanding, and lay the foundations for social and public support for regional cooperation. These five aspects ultimately seek to create material and institutional interconnection between China and other BRI countries (Zhao, 2015).

There are three principles that structure the BRI as a systematic project (National

Development and Reform Commission, Ministry of Foreign Affairs, \& Ministry of Commerce, 2015). 1) Extensive consultation: All countries within the BRI should engage in 
brainstorming and strengthened communication and discussion as well as have their interests and concerns accounted for, be granted an equal voice, and be able to express their wisdom and creativity. 2) Joint communication: All countries within the BRI should actively cooperate with each other and jointly assume responsibilities to build regional cooperation mechanisms and rules. 3) Shared benefits: All countries within the BRI should cooperatively share developmental achievements and ensure that these achievements benefit peoples within the BRI in an equitable manner.

The BRI's overarching objectives are cooperation to assemble a community of shared interests, destiny, and responsibilities, characterized by mutual trust, economic integration, and cultural inclusiveness, ultimately contributing to a shared future for humanity (Liang, 2018). This shared future should take the form of a world of lasting peace, universal security, common prosperity, openness and inclusiveness, and cleanliness and beauty (Xinhua News Agency, 2017). This is a vision of the world in which the success of one country can only be guaranteed by the success of all. The BRI is only a success if all its member states develop and prosper in tandem.

It is a great paradox of the BRI that, although it has at a formal level been envisioned as an international system for joint development, enhanced cooperation and understanding, deepening of relations as such, and provision of global public goods, this vision has largely been formulated by the Chinese government and in line with Chinese cultural and political traditions. Furthermore, the extent to which other countries or, indeed, Chinese business actors buy into these ideals is uncertain, and it is altogether possible that short- and mediumterm economic benefit (rather than ideals of a radically interconnected, peaceful, and interdependent world) is the primary motivation for many of the individual activities undertaken within the BRI. The BRI's vision of 'inclusive globalization' (Liu \& Dunford, 2016) often depends upon business and government actors with more limited conceptions of their own interests. Furthermore, as Zhai (2018, p. 85) notes, "the BRI is still a flexible conceptual initiative and far from a well-defined action plan with top-down design. The vagueness of the BRI program leads to difficulties in quantitatively evaluating its economic impact." One result of this vagueness is that it is far too easy to look past discordant goals and impacts within the BRI.

Such disconnects become especially clear when we consider the BRI's failure so far to devote much attention to issues of island sustainability, including climate change adaptation. If we are to take seriously the BRI's aims of lifting all countries up together and ensuring that interests and responsibilities are shared, then we would expect the BRI to devote particular attention to assisting its smallest and so-called most-vulnerable member states with precisely those globalized problems that these states are unable to cope with themselves.

Having considered the global nature of problems and solutions as well as the framework for the BRI, we now proceed to consider the ways in which climate change in particular is affecting island communities and in which the BRI ought to address this global problem.

\section{Climate change and small islands}

The global climate system is changing rapidly, with the average temperature on the Earth's surface today being $1^{\circ} \mathrm{C}$ higher than before industrialization (Cai, 2018; IPCC, 2014). Climate scientists and international organizations such as the United Nations have repeatedly 
called upon countries to take measures to reduce greenhouse gas emissions, yet these emissions still reached an all-time global high in 2018 (Song \& Liu, 2019).

Although actual climate impacts are complex and never exist in isolation from other factors (Kelman, 2018), climate change represents a significant influence on the prosperity, wellbeing, and potentially survival of many small island states and territories (Xu, 2019; Halstead, 2016), with potential negative impacts including rising sea levels, marine life changes, water shortages, devastating heat waves, and altered weather patterns (including extreme weather).

Many of these impacts are not limited to islands but will affect coastal environments in general (Tibbetts et al, 2013). The coastal zone, which represents an interface space between land and sea, is highly dynamic and highly sensitive to changes in climatic conditions (Carmo, 2018). One reason why many small island communities may be at special risk from climate change is simply that they tend to have disproportionately high coast-area ratios. It is not necessarily that small islands possess greater 'absolute vulnerability'; they may sometimes simply possess greater 'proportional vulnerability' (Kelman, 2020). Small islands may be particularly likely to be comprehensively impacted by climate change, even if the seriousness of climate change is no greater on islands than elsewhere. The same may apply to low-lying 'mainland' states with long coastlines (Baldacchino \& Kelman, 2014, pp. 3-4), such as Bangladesh, Indonesia, and Vietnam, all important BRI members states. Yet such a distinction may be of little help to small island communities that experience proportionately greater impacts and sometimes lack the terrestrial hinterlands to provide alternative livelihoods, basic resources, housing, etc.

Although anthropogenic climate change is recognized as a global problem requiring global solutions, existing cooperation mechanisms at the international level have proved insufficient, both in terms of achieving mitigation and encouraging adaptation. Even if countries immediately ceased greenhouse gas emissions, the impacts of past emissions will persist for decades (IPCC, 2014). As a result, while it is important that large countries work urgently to mitigate climate change by reducing greenhouse gas emissions, it is also necessary that countries take steps to adapt to emergent and future climate change impacts.

According to the Intergovernmental Panel on Climate Change, "adaptation is the process of adjustment to actual or expected climate and its effects in order to avoid harm or exploit beneficial opportunities" (IPCC, 2014, p. 76). Although national, international, and nongovernmental bodies are active in supporting island states and territories with climate change adaptation, current levels of assistance do not come close to meeting adaptation needs (Mycoo, 2018; Robinson, 2017; Robinson \& Dornan, 2017). Climate change adaptation assistance to small island states and territories has not managed to escape the pitfalls associated with competitive interstate relations, commercialization, and focus on donor (rather than recipient) needs and concerns (Grydehøj \& Kelman, 2020; Perumal, 2018; Webber, 2017). That is, while climate security can be seen as a global public good, it is currently being supplied in a highly uneven manner. Moreover, the same large and wealthy states that are disproportionately high emitters of greenhouse gases and thereby bear the most responsibility for climate change impacts are called upon to assist other countries with climate change adaptation efforts: their failure to do so efficiently, sufficiently, or in a manner that meets local needs may simply compound the damage, deepening island-mainland dependencies without effectively boosting sustainability.

There is thus a need not just for increasing climate change adaptation support to island states and territories but also rethinking the frameworks in which this support is offered. 


\section{The Belt and Road Initiative's potential for promoting island climate change adaptation cooperation}

Most of the countries within the BRI's $21^{\text {st }}$-Century Maritime Silk Road are developing states, with poor levels of infrastructure, significant funding gaps, and inability to invest in technologies or industrial shifts that can assist with climate change adaptation (Ding \& Zhang, 2018).

Although cooperation, policy coordination, and mutually beneficial development are cornerstones of the BRI, the BRI has yet to produce a powerful regional (much less global) climate change response cooperation mechanism. There are a number of sub-regional climate change mitigation efforts between BRI countries, but climate change adaptation cooperation has been largely absent. There is a severe lack of cooperative sharing of information and experiences, lack of sharing of technological advances, and lack of financial support, hindering climate change adaptation efforts. This calls into question whether the BRI is truly delivering its promised sustainable development benefits (Zhong \& Wu, 2020).

The BRI has not yet been a source of progress in small island climate change adaptation, but it does present the potential for positive change. Countries and territories within the BRI have gradually recognized the need for geographical integration and mutual cooperation, both within and across regions. The establishment of BRI cooperation mechanisms, including cooperation mechanisms for climate change adaptation, has gradually risen on the policy agenda.

Small island states and territories may be among the places within the BRI that come to suffer the most extreme impacts from climate change, but they may also be among the places that have the most to benefit from BRI-facilitated coordination efforts. The BRI's envisioned new model of international cooperation offers the potential to escape some of the traditional pitfalls of reliance on mainstream, state-centric international cooperation systems for the production, supply, and distribution of global public goods. The conceptual core of $\mathrm{BRI}$ is to coordinate collective actions to solve public problems and to focus on infrastructure construction, economic integration, financial cooperation, and environmental protection, which have the characteristics of non-competitive and non-exclusive public goods ( $\mathrm{He}$, 2018). Cooperation concerning small island climate change adaptation constitutes an important aspect of ecological security and sustainability, which is a key element of the BRI framework (Zhong \& Wu, 2020).

The BRI's focus on shared interests and responsibilities provides a conceptual basis for mainland states and territories within the BRI to regard small island climate change adaptation as relevant and as part of their 'internal affairs' - thereby encouraging coordinated and cooperative responses. That is, the BRI helps expand conceptualizations of the 'public' to which a particular government is responsible for providing public goods.

Global public goods are interconnected and interdependent, much like the global public itself. Infrastructure construction is driven by and depends upon economic development, economic development promotes and requires public security, and public security improves and relies upon environmental protection. Within globalization, it is necessary to coordinate the production and supply of multiple types of public goods. The production and supply of different types of public goods at the global level is currently fragmented and covered by different international legal systems and supranational bodies, which may not be simply disconnected but may also be in conflict with one another. For example, the World Trade Organization's role in managing global public goods related to the economy is not always 
amenable to the Intergovernmental Panel on Climate Change's role in analyzing how ecological public goods should be managed, even though both types of public goods are interdependent.

States and territories within the BRI have begun to characterize climate change's influences on other countries as detrimental to the common interests of all countries because they directly affect internal interests and progress. Increasingly, it is understood that all interests are relational, and all goods are shared (Qin, 2018). This motivates ideas of mutual aid (rather than self-help) and partnership as a reaction to climate change, undergirded by concepts that have been built into the Chinese state's BRI vision, such as the principles of 'cooperation and win-win', 'responsibility sharing', 'collaborative leadership', and 'justice and equality' (Huang, 2018).

On a conceptual level, China has made climate change adaptation cooperation a significant part of the BRI's sustainable development agenda (Wang et al, 2018). The core document of the BRI, namely Vision and Actions on Jointly Building Silk Road Economic Belt and 21st-Century Maritime Silk Road (National Development and Reform Commission, Ministry of Foreign Affairs, \& Ministry of Commerce, 2015), emphasizes "taking full account of the impact of climate change in construction" and "strengthening cooperation in tackling climate change." In April and May 2017, the Guidelines on Promoting Green BRI and the BRI Ecological Protection Cooperation Plan (Ministry of Ecology and Environment, 2017a, 2017b) issued by the Chinese government both emphasized the response to climate change and reiterated the provisions of Vision and Actions on Jointly Building Silk Road Economic Belt and 21st-Century Maritime Silk Road to strengthen climate change cooperation.

The construction of a so-called 'Green BRI' proposes the integration of environmental protection into all aspects of BRI construction, the sharing of China's own experiences in attempting to construct an 'ecological civilization', and efforts to improve the ability of countries within the BRI to protect the environment and guard against environmental hazards. At the second Belt and Road Forum for International Cooperation, held in April 2019, China announced the implementation of the Belt and Road South-South Cooperation Initiative on Climate Change, and as early as September 2015, China announced that it would invest RMB 20 billion to establish the China South-South Climate Cooperation Fund to support other developing countries in addressing climate change (Ding \& Zhang, 2018).

The BRI's pursuit of comprehensive, balanced, fair, and sustainable globalization, including cooperation on climate change adaptation, could develop into a powerful new response to globalization and powerful new model for win-win international cooperation (Wang, 2015). China, as the initiator of and a key actor within the BRI, has invested large sums of money in the BRI project, including in the newly established Asian Infrastructure Investment Bank and the Silk Road Fund. This is in line with China's self-understanding as a country with a special responsibility to promote global governance (Jin, 2017).

Nevertheless, for all the lofty discourse, the BRI's ability to serve as a vehicle or framework for global governance on climate change adaptation remains unproven.

\section{Framework for island climate change adaptation cooperation within the Belt and Road Initiative}

Global climate change and its accompanying impacts may not only affect small island communities within the BRI but also restrict the smooth implementation of the BRI as a 
whole. Since no country within the BRI can manage climate change's influences alone, all countries within the BRI must carry out all-round cooperation in adapting to climate change.

We now set forth how small island climate change adaptation can be foregrounded within the BRI. While acknowledging that China is the main proponent of the BRI, it is important to bear in mind that BRI is conceptually grounded in equal relationships of mutual respect, an ideal of policy coordination, and a desire for intercommunity bonding and closer communication between peoples. That is, if the BRI is to succeed on the terms that China has envisioned, the activities within it must be jointly created, driven, and carried out with island communities. Small island states and territories are not merely objects upon which policy can be targeted; small island interests and motivations for their own development are essential.

We propose that the basic framework for small island climate change adaptation cooperation within the BRI be built on four key aspects: information sharing, scientific and technological cooperation, financial support, and capacity building.

\section{Information sharing}

Climate change has highly localized impacts; it is a global phenomenon that is and will be experienced in different ways in different places. For example, although both Mauritius and Maldives are Indian Ocean island states within the BRI, they possess distinct geographical, economic, and demographic characteristics that affect the aspects of climate change adaptation that they must prioritize.

Accurate and reliable information is essential for countries, territories, and communities to adapt to climate change. It is not only the basis for action but also the basis for scientific decision-making. To this end, Article 7, $\$ 7$ of the Paris Agreement (United Nations, 2015) emphasizes that all parties should strengthen cooperation in enhancing adaptation actions, including the exchange of information, good practices, experiences, and lessons learned. China has officially launched a big data service platform website (http://eng.greenbr.org.cn/) for environmental protection within the BRI and is accelerating the construction of the 'Digital Silk Road'. These initiatives have the potential to assist information sharing concerning climate change adaptation among countries within the BRI.

However, fully sharing information on climate change adaptation requires more than just the establishment of a network platform. It also requires the creation of a comprehensive cooperation mechanism that strengthens and supplements relevant provisions of the Paris Agreement. Some provisions of the mechanism should specify the types, channels, and management of information sharing. As the BRI states it is dedicated to building a community of shared interests, a community of shared responsibilities, and a community of common destiny, countries within the BRI should be encouraged to fully share information related to such issues as science and technology, law and policies, statistical data, and typical cases. Additionally, relevant information should be fully and conveniently provided to promote effective cooperation on climate change adaptation. This must be about true communication of interests and efforts at mutual understanding, not about activities aimed at acquiring competitive advantage.

\section{Scientific and technological cooperation}

Science and technology are of great significance for climate change mitigation and adaptation (Xu et al, 2018). It is thus that Article 10, $\$ 1-2$ of the Paris Agreement (United Nations, 
2015) states that all parties share a long-term vision for full implementation of technology development and transfer to improve resilience to climate change and reduce greenhouse gas emissions. Despite the massive demand for science and technology to adapt to climate change, levels of scientific and technological development vary widely among BRI countries. It is necessary to create a scientific and technological cooperation regime within the BRI to address climate change, promoting the joint development and exchange of relevant science and technology as well as the expertise concerning it.

By positioning climate change adaptation as a global public good and thereby challenging traditional intellectual property protection restrictions, countries within the BRI may be able to coordinate agreements on scientific and technological cooperation and technology exchange. In order to promote the exchange of environmental technologies, China's Ministry of Ecology and Environment (2019) established the BRI Environmental Technology Exchange and Transfer Center. At the Belt and Road Forum for International Cooperation held in mid-May 2017, China announced the launch of the BRI action plan for scientific and technological innovation, carrying out scientific, technological and people-topeople exchanges; joint laboratory co-construction; cooperation in science and technology parks; and technology exchange. The forum committed to arranging for 2500 young scientists to undertake short-term scientific research in China over the following 5 years, training 5000 people in science, technology and management; and establishing 50 joint laboratories.

\section{Financial support}

Article 9, $\$ 1$ of the Paris Agreement (United Nations, 2015) stipulates that developed countries should provide funding to assist developing countries with climate change mitigation and adaptation. In October 2014, the Asian Infrastructure Investment Bank, which has legal capital of US $\$ 100$ billion (Sina Finance, 2014), was established in order to promote infrastructure interconnection and economic integration in Asia. In October 2014, the Silk Road Fund was established with a legal capital of US $\$ 40$ billion. In order to increase financial support for the construction of BRI, China decided in May 2017 to add RMB 100 billion to the Silk Road Fund and encourage financial institutions to provide around RMB 300 billion to fund BRI business development. The World Bank, New Development Bank created by BRICS (Brazil, Russia, India, China, and South Africa), and other multilateral development agencies have likewise pledged to support the BRI project (People's Daily, 2017; Shanghai Observer, 2017; Xinhua News Agency, 2018).

Global action on climate change adaptation is also being encouraged by the China SouthSouth Climate Cooperation Fund, which seeks to support developing states in transitioning to green low-carbon development and climate change adaptation (China News Center, 2015). The Asian Development Bank (2017) has, however, estimated that developing Asia will require investments of US $\$ 26$ trillion from 2016 to 2030. Countries within the BRI will thus need to carry out more extensive cooperation in the future in order to expand financing channels, obtain greater financial support from the existing Global Environment Facility, Adaptation Fund, and Green Climate Fund while at the same time increasing their own financial contributions. In addition, in light of the special needs that are frequently attributed to small island states and territories, countries within the BRI should consider establishing a climate change adaptation fund specifically for small island communities and financing through various channels, which requires BRI countries to create special cooperation arrangements. 


\section{Capacity building}

All countries benefit when all countries possess the ability to adapt to climate change. The interests of wealthy and developed countries cannot be separated from those of developing countries. Article 11, $\$ 1$ of the Paris Agreement (United Nations, 2015) stipulates the strengthening of capacity building in developing countries, especially those with the weakest capacity and the most vulnerability to the adverse effects of climate change, as small island developing states are often labelled. Even full cooperation among countries within the BRI in the areas of information, science, technology, and finance will not ensure the ability of small island states and territories to adapt to climate change. Because capacity building is a continuing project, financing and technology must be supplemented by personnel training, climate change governance mechanisms, and the reform and improvement of legal framework. This highlights the necessity of establishing an innovative cooperation regime for small island climate change adaptation within the BRI.

China for its part has initiated supplies of materials and support for project construction, technical cooperation, and personnel training, especially in the construction of 10 low-carbon demonstration zones in developing countries within the BRI, 100 climate change mitigation and adaptation projects, and cooperation projects involving the training of 1000 individuals in climate change response. In 2019, China also implemented the Green Silk Road Envoys plan, which provides 1500 officials from national environmental departments with training to facilitate the joint construction of an environmentally sustainable BRI over a three-year period.

\section{China's role in leading climate change adaptation within the Belt and Road Initiative}

If the BRI is to fulfil its potential for assisting small island states and territories with climate change adaptation, it cannot simply be a Chinese initiative. Other wealthy and powerful countries within the BRI must also contribute, not simply with money and with material resources but also by committing to the shift in global governance and international cooperation that the BRI entails. The same goes for small island states and territories, which ought to be equal partners and have a powerful say in the development of the BRI. If the BRI is seen primarily as an initiative run by and for the benefit of the Chinese state, then other states will not contribute, which will ultimately prompt Chinese concern over freeriding in the production, supply, and distribution of global public goods. Only by working together can countries ensure that global public goods are enjoyed by all.

We have outlined above a vision for climate change adaptation cooperation within the BRI framework, with special focus on small island states and territories. This vision is not yet a reality, in part because the BRI as a whole has not yet been fully developed and in part because the BRI's conceptual emphasis on sustainable development is not always reflected in individual BRI-linked projects (Zhong \& Wu, 2020). It also needs to be acknowledged that the Chinese state has at times been insufficiently attentive to the need to consistently foreground the BRI's conceptual basis at the level of these individual projects.

China cannot enforce adoption of new modes of international cooperation, but its unique role in conceptualizing and constructing the BRI makes it responsible for demonstrating leadership in working toward the global interest and supporting mutually beneficial development processes. China has a responsibility to not just work in its own interests. 
In order to promote cooperation on small island climate change adaptation within the BRI, we recommend that China adopt a plan characterized by three key attributes: top-level and long-term planning, creating a cooperation mechanism, and adjusting foreign aid.

Top-level and long-term planning

China should develop a top-level design and long-term plan for cooperation on climate change adaptation in the BRI as soon as possible. This plan should set a clear timetable and road map for China and other countries within the BRI to adapt to climate change. This would strengthen confidence in the BRI's potential among participating countries and would promote investment in international cooperation. The basic document of BRI, Vision and Actions (National Development and Reform Commission, Ministry of Foreign Affairs, \& Ministry of Commerce, 2015), emphasizes the importance of "strengthening cooperation on climate change," an aim that is reiterated in the core document for promoting the construction of a Green BRI, the Plan for Cooperation in Ecological Protection for the Belt and Road Initiative (Ministry of Ecology and Environment, 2017b). Nevertheless, such top-level documents have not led to a credible cooperation plan for climate change adaptation within the BRI. If prioritized by China, planning of this kind could yield real results in terms of speeding up and strengthening cooperation on climate change adaptation (Ding et al., 2018).

Such top-level planning would not be a replacement for engagement and exchange of ideas across communities. It would instead be a means of structuring discussion and knowledge sharing between island communities, China, and other BRI partners to ensure that everyone's needs were being addressed.

\section{Creating a cooperation mechanism}

China should speed up the creation of a climate change adaptation cooperation mechanism for countries within the BRI. The existence of such a cooperation mechanism is the basic precondition for making the Green BRI vision a reality. Policy coordination is an important aspect of the BRI, dependent upon "strengthening intergovernmental cooperation and actively building a multi-level intergovernmental macro-policy communication and exchange mechanism" (National Development and Reform Commission, Ministry of Foreign Affairs, \& Ministry of Commerce, 2015). All BRI countries are also parties to the Paris Agreement, which requires deepening cooperation on climate change response.

The Meteorological Development Plan of the BRI (2017-2025), established by the China Meteorological Administration (2018), for its part shows awareness of the necessity of creating a cooperation mechanism to address climate change. This plan seeks to create channels for communication between relevant meteorological authorities in BRI countries in order to develop climate change policies, improve mechanisms for intergovernmental cooperation and exchange, improve cooperation mechanisms for BRI disaster prevention and reduction, and strengthen capacity to respond to climate change.

Guided by the aforementioned top-level, long-term design, the Chinese state can adjust the focus of its foreign aid and collaborate with other BRI countries to create a cooperation mechanism for climate change adaptation. The resultant mechanism should be positioned to rely upon and develop existing multilateral, regional, and bilateral cooperation mechanisms within the BRI. That is, the cooperation mechanism should belong to and represent the interests of all BRI states, including its numerous small island states. It should produce more 
detailed and operational provisions on climate change adaptation in countries within the BRI, drawing inspiration from the Paris Agreement, but it should also establish supplementary and expansive regulations by integrating existing relevant regional and bilateral agreements between BRI countries. The BRI framework is ideal for giving small island states and territories a voice and a stake in this cooperation, inasmuch as it insists upon mutually beneficial development and the existence of a community of shared destiny.

\section{Adjusting foreign aid}

China's foreign aid recipient countries and its aid projects should be adjusted to take into account the seriousness of the challenges they face and their existing capacity to manage these challenges. For small island states and territories, like all states and territories, the challenges of climate change adaptation are intimately linked with other political, economic, social, and environmental factors. An island's ability to manage climate change is inevitably connected to its government's ability to plan and implement policy, its people's ability to secure fulfilling livelihoods, and its complex set of interdependencies with other states and territories. A BRI focus on climate change should guide China's foreign aid in new directions and should empower and grant impetus to networks for international cooperation. China could, for example, consider shifting the focus of foreign aid to support developing countries within the BRI in their response to climate change, especially when it comes to those communitieslike island communities - that are often said to be most comprehensively at risk. Only by safeguarding everyone's future can anyone's future be assured.

The proportion of China's foreign aid dedicated to climate change adaptation per se should also be increased, following trends over recent years. As early as 2005, China was contributing to the construction of a 'safe island' housing project in Maldives to protect local residents from tsunamis and coastal erosion (He, Ying, \& Zhang, 2005). The Chinese state has also assisted Bangladesh and Maldives in establishing early warning systems for extreme weather. However, the total sum of aid dedicated to climate change-related projects remains small relative to other BRI focus areas. In 2015, China began a large series of new aid projects aimed at developing countries over the subsequent five years (People's Daily, 2015). Given the close links between climate change adaptation and poverty alleviation, disaster risk reduction, and agricultural production, it makes sense to integrate a climate change adaptation element into wider thrusts of aid.

\section{Conclusions}

This paper has asked how China can refocus its efforts within the BRI to better meet the needs of island states and territories that face challenges related to sustainable development, including climate change adaptation. Many of the countries participating in the BRI in general and the $21^{\text {st }}$-Century Maritime Silk Road in particular have failed to take adequate climate change adaptation measures, often claiming lack of resources (human, financial, technological, knowledge).It is necessary to establish a BRI island cooperation mechanism for climate change adaptation, one informed by a top-level, long-term plan and supported by foreign aid and other forms of mutual assistance. All those influenced by environmental changes deserve protection and aid on humanitarian grounds (Docherty \& Giannini, 2009), and the tools and technologies for coping with climate change should be seen as global public goods. 
The BRI has been conceptualized by the Chinese state as a framework for cooperation toward building a better future for all humankind. Only by ensuring that the interests of all states, territories, and peoples are addressed can this project fulfil its potential. If the BRI's conceptual basis is to be taken seriously, focused attention must be placed on small island communities precisely because these have often been regarded as peripheral to global discussions and concerns. In the future, small island communities must be seen as equal partners in a forming and informing a new, sustainable, and equitable system of global governance.

\section{Funding}

Fujian Social Science Planning Project of China (Project No.: FJ2019B006).

\section{References}

Aminzadeh, S.C. (2007). A moral imperative: The human rights implications of climate change. Hastings International and Comparative Law Review, 30, 231-265.

Asian Development Bank (2017). Meeting Asia's infrastructure needs. Asian Development Bank. https://www.adb.org/publications/asia-infrastructure-needs.

Baldacchino, G., \& Kelman, I. (2014). Critiquing the pursuit of island sustainability: Blue and Green, with hardly a colour in between. Shima, 8(2), 1-21.

Cai, J. (2018). The global temperature may rise $1.5^{\circ} \mathrm{C}$ ahead of schedule. Eco-Economy 34(12), $2-5$.

Carmo, J.S.A. (2018). Climate change, adaptation measures, and integrated coastal zone management: The new protection paradigm for the Portuguese coastal zone. Journal of Coastal Research, 34(3), 687-703. https://doi.org/10.2112/jcoastres-d-16-00165.1

Chen, M., Zhang, L., Teng, F., Dai, J., Li, Z., Wang, Z., \& Li, Y. (2020). Climate technology transfer in BRI era: needs, priorities, and barriers from receivers' perspective. Ecosystem Health and Sustainability, 6(1), 1-12. https://doi.org/10.1080/20964129.2020.1780948

China News Center (2015, September 27). China to allocate 20 billion yuan to build the China South-South Climate Cooperation Fund. China News Center. http://news.china.com.cn/2015-09/27/content 36692444.htm

Chun, Z. (2017). The Belt and Road Initiative and global governance in transition. China Quarterly of International Strategic Studies, 3(02), 175-191. https://doi.org/10.1142/s2377740017500166

China Meteorological Administration (2018). The Meteorological Development Plan of the BRI (2017-2025). China Meteorological Administration. http://www.cma.gov.cn/2011xwzx/2011xqxxw/2011xqxyw/201801/t20180109 45 9713.html.

Docherty, B., \& Giannini, T. (2009). Confronting a rising tide: A proposal for a convention on climate change refugees. Harvard Environmental Law Review, 33, 349.

Ding, J., \& Zhang, C. (2018). The construction of Belt and Road Initiative and international climate governance. Modern International Relations, 9.

Dunford, M., \& Liu, W. (2019). Chinese perspectives on the Belt and Road Initiative. Cambridge Journal of Regions, Economy and Society, 12(1), 145-167. https://doi.org/10.1093/cjres/rsy032 
Fidler, D.P. (2003). SARS: Political pathology of the first post-Westphalian pathogen. The Journal of Law, Medicine \& Ethics, 31(4), 485-505. https://doi.org/10.1111/j.1748720x.2003.tb00117.x

Gómez-Barris, M., \& Joseph, M. (2019). Coloniality and islands. Shima, 13(2), 1-10. https://doi.org/10.21463/shima.13.2.03

Grydehøj, A., \& Kelman, I. (2020). Reflections on conspicuous sustainability: Creating Small Island Dependent States (SIDS) through Ostentatious Development Assistance (ODA)?. Geoforum, 116, 90-97. https://doi.org/10.1016/j.geoforum.2020.08.004

Halstead, E. (2016). Citizens of sinking islands: Early victims of climate change. Indiana Journal of Global Legal Studies, 23(2), 819-838. https://doi.org/10.2979/indjglolegstu.23.2.0819

He, C. (2018). The Belt and Road Initiative as global public good: Implications for international law. Springer.

He, M., Yin. D., \& Zhang. X. (2005, August 29). China's aid projects in Sri Lanka and Maldives are progressing smoothly. China News Network. http://www.chinanews.com/news/2005/2005-08-29/8/618069.shtml.

Huang, H., \& He, P. (2018). The Belt and Road Initiative and regional public goods. Shanghai People's Publishing House.

IPCC (2014). Climate change 2014: Synthesis report. Contribution of Working Groups I, II and III to the fifth assessment report of the Intergovernmental Panel on Climate Change. [Core Writing Team, R.K. Pachauri, \& L.A. Meyer (Eds.). IPCC.

Jin, N., et al. (2017). China's responsibility for global governance. Renmin University of China Press.

Kaul, I., Grunberg, I., \& Stern, M. A. (1999). Defining global public goods. In: I. Kaul, I. Grunberg, \& M.A. Stern (Eds.), Global public goods: International cooperation in the 21st century (pp. 2-19). New York: United Nations Development Program. https://doi.org/10.1093/0195130529.003.0001

Kelman, I. (2020). Islands of vulnerability and resilience: Manufactured stereotypes?. Area, 52(1), 6-13. https://doi.org/10.1111/area.12457

Kelman, I. (2017). How can island communities deal with environmental hazards and hazard drivers, including climate change?. Environmental Conservation, 44(3), 244-253. https://doi.org/10.1017/s0376892917000042

Lanteigne, M. (2018). Chinese foreign policy: An introduction. Routledge.

Liang, H., \& Zhang. Y. (2018). The twenty-four major theoretical issues in the Belt and Road. People's Publishing House.

Liu, W., \& Dunford, M. (2016). Inclusive globalization: Unpacking China's belt and road initiative. Area Development and Policy, 1(3), 323-340. https://doi.org/10.1080/23792949.2016.1232598

McCall, G. (1994). Nissology: a proposal for consideration. Journal of the Pacific Society, 63- 64(17), 93-106.

Ministry of Ecology and Environment (2019). Green has become the background for the construction of the Belt and Road: Overview of the green development achievements of the Second Belt and Road Forum for International Cooperation. Ministry of Ecology and Environment. http://www.mepfeco.org.cn/dtxx/xwdt/201905/t20190506 702025.html 
Ministry of Ecology and Environment (2017a). Guidelines on promoting Green BRI. Ministry of Ecology and Environment. http://www.mee.gov.cn/gkml/hbb/bwj/201705/t20170505 413602.htm

Ministry of Ecology and Environment (2017b). Notice on the issuance of the Plan for Cooperation in Ecological Protection for the Belt and Road Initiative. Ministry of Ecology and Environment. http://www.mee.gov.cn/gkml/hbb/bwj/201705/t20170516 414102.htm

Mitrovic, D. (2018). China's Belt and Road Initiative: Connecting and transforming initiative. Palgrave Macmillan. https://doi.org/10.1007/978-981-10-5921-6 2

Mycoo, M.A. (2018). Beyond 1.5 C: vulnerabilities and adaptation strategies for Caribbean Small Island developing states. Regional Environmental Change, 18(8), 2341-2353. https://doi.org/10.1007/s10113-017-1248-8

National Development and Reform Commission, Ministry of Foreign Affairs, \& Ministry of Commerce (2015). Vision and actions on jointly building Silk Road Economic Belt and 21stCentury Maritime Silk Road. Ministry of Foreign Affairs of the People's Republic of China. https://www.fmprc.gov.cn/mfa eng/zxxx 662805/t1249618.shtml

People's Daily (2017). World Bank President Jim Yong Kim: Belt and Road Initiative will help world development. People's Daily. http://world.people.com.cn/n1/2017/0515/c1002-29276539.html

People's Daily (2015, September 29). Xi Jinping attended the general debate of the Seventieth United Nations General Assembly and delivered important speeches. People's Daily.

Perumal, N. (2018). "The place where I live is where I belong”: community perspectives on climate change and climate-related migration in the Pacific island nation of Vanuatu. Island Studies Journal, 13(1), 45-64. https://doi.org/10.24043/isj.50

Puig., G.V. (2020). Free trade areas for China's Belt and Road. Currents, 24, 3.

Qin, Y. (2018). A relational theory of world politics. Cambridge University Press.

Qin, Y. (2003). National identity, strategic culture, and security interests: Three hypotheses on the interaction between China and the international community. World Economics and Politics, 1.

Ren, X. (2020). Grown from within: Building a Chinese School of International Relations. The Pacific Review, 33(3-4), 386-412. https://doi.org/10.1080/09512748.2020.1728573

Robinson, S.A. (2017). Climate change adaptation trends in small island developing states. Mitigation and Adaptation Strategies for Global Change, 22(4), 669-691. https://doi.org/10.1007/s11027-015-9693-5

Robinson, S.A., \& Dornan, M. (2017). International financing for climate change adaptation in small island developing states. Regional Environmental Change, 17(4), 1103-1115. https://doi.org/10.1007/s10113-016-1085-1

Shanghai Observer (2017, May 14). BRICS New Development Bank: May seek private nonsovereign business in the BRI project. Shanghai Observer. https://www.jfdaily.com/news/detail?id=53117.

Sina Finance (2014, October 24). 21 countries signed an agreement to establish the Asian Infrastructure Investment Bank with a legal capital of 100 billion US dollars. Sina Finance. http://finance.sina.com.cn/world/yzjj/20141024/154620634444.shtml 
Song, F., \& Liu, Z. (2019). Global carbon emissions hit a new high in 2018. Ecological Economy, 2019, 35(02), 5-8.

Speth, J.G. (1999). Forward. In: I. Kaul, I. Grunberg, \& M.A. Stern (Eds.), Global public goods: International cooperation in the 21st century (pp. xii-xiv). United Nations Development Program.

Tibbetts, J.R., \& Proosdij, D. V. (2013). Development of a relative coastal vulnerability index in a macro-tidal environment for climate change adaptation. Journal of Coastal Conservation, 17, 775-797. https://doi.org/10.1007/s11852-013-0277-9

United Nations (2015). The Paris Agreement. United Nations Framework Convention on Climate Change. https://unfccc.int/process-and-meetings/the-paris-agreement/theparis-agreement

Wang, W., Teng, F., Zhu, S., Nan, Y. \& Liu, Y. (2018). New reflections on green development strategy of China addressing on the global climate governance. China Population, Resources and Environment, 28(7), 3.

Wang, Y. (2015). The Belt and Road Initiative: Opportunities and challenges. People's Publishing House.

Webber, S. (2017). Circulating climate services: Commercializing science for climate change adaptation in Pacific Islands. Geoforum, 85, 82-91. https://doi.org/10.1016/j.geoforum.2017.07.009

Winter, T. (2018). Geocultural power: China quest to revive the Silk Roads for the Twenty-First Century. University of Chicago Press. https://doi.org/10.7208/chicago/9780226658490.001.0001

Xi, J. (2015). Working Together to Forge a New Partnership of Win-win Cooperation and Create a Community of Shared Future for Mankind (New York, 28 September 2015). Embassy of the People's Republic of China in the Republic of Fiji. http://fj.chinaembassy.org/eng/topic/xjpjh/t1321127.htm

Xie, B., Zhu, X., \& Grydehøj, A. (2020). Perceiving the Silk Road Archipelago: Archipelagic relations within the ancient and 21st-Century Maritime Silk Road. Island Studies Journal, 15(2), 55-72. https://doi.org/10.24043/isj.118

Xinhua News Agency (2018, July 2). Jin Liqun: The Asian Infrastructure Investment Bank actively supports the Belt and Road Initiative and has approved an investment of over US $\$ 5.3$ billion. Xinhua News Agency.

Xinhua News Agency (2017, January 19). Xi Jinping attends high-level conference on building a community of shared future for mankind" and delivers keynote speech. Xinhua News Agency. http://news.xinhuanet.com/world/201701/19/c 1120340049.htm

Xu, D., Wang, Z., Ding, X., Li, D., \& Song, A. (2018). Research on the policy environment for promoting scientific and technological innovation to adapt to climate change. Science and Technology Management Research, 2.

$\mathrm{Xu}$, H. (2019). Poland Climate Conference rescued Paris Agreement. Ecological Economy, $35(2), 1-4$.

Xu, S., \& Jiang, M. (2013). Study on the impact of climate change on islands. Ocean Development and Management, 30(12), 28-31+45.

Yan, X. (2019). Leadership and the rise of great powers. Princeton University Press. 
Zhai, F. (2018). China's belt and road initiative: A preliminary quantitative assessment. Journal of Asian Economics, 55, 84-92. https://doi.org/10.1016/j.asieco.2017.12.006

Zhang, Feng. 2013. "The rise of Chinese exceptionalism in international relations." European Journal of International Relations 19, no. 2: 305-328.

Zhao, K. (2015). The Belt and Road: from vision to actions. Peking University Press.

Zhong, S., \& Wu, X. (2020). Indian Ocean island sustainable development in the context of the 21st-Century Maritime Silk Road. Island Studies Journal, 15(2). Epub ahead of print. https://doi.org/10.24043/isj.117

Zhao, T. (2009). A political world philosophy in terms of all-under-heaven (Tianxia). Diogenes, 56(1), 5-18. https://doi.org/10.1177/0392192109102149 
Chunlin Li, Jianqing Chen, \& Adam Grydehøj 